Bożena WóJTOWICZ

Uniwersytet Pedagogiczny, Kraków, Polska • Pedagogical University of Cracow, Poland

\title{
Centra handlowe jako miejsca ustug turystycznych w zakresie spędzania wolnego czasu przez mieszkańców Kielc
}

\author{
Shopping malls as tourist services sites \\ for spending free time by the inhabitants of Kielce
}

Streszczenie: Centra handlowe pojawiły się w przestrzeni miejskiej Polaków jako miejsce zakupów. Jednak współczesne społeczeństwo nieco inaczej widzi rolę zakupów w centrach handlowych. Z czynności obowiązkowych zakupy przemieniły się w przyjemność oraz formę zagospodarowywania i spędzania wolnego czasu. Wizyty w centrach handlowych stały się generatorem przemieszczeń ludności oraz zachowań związanych z czasem wolnym wielu konsumentów. Celem artykułu jest przedstawienie na podstawie badań diagnostycznych roli, jaką we współczesnym świecie ogrywają zakupy dla mieszkańców średnich miast, oraz wskazanie, na ile centra handlowe stanowią dla nich formę usług turystycznych, np. spędzania wolnego czasu. Przedstawiono model zachowań konsumenckich, który stanowi przejaw nowego stylu życia wykreowanego przez młode pokolenie w galeriach handlowych.

\begin{abstract}
Shopping malls (centres) have appeared in the Polish urban space as a place for shopping. Modern society sees the role of shopping malls slightly differently. Shopping changed from obligatory actions to a pleasure and a form of leisure activities. Visits to shopping malls have become a generator of population movements and behaviours associated with leisure time of many consumers. The aim of this paper is to present the role of shopping in the today world, on the basis of the diagnostic tests. Such research covered the role of shopping for the residents of medium sized cities and how shopping malls/ centres are, to them, a way of spending free time. The article presents the model of consumer behaviour, which is the manifestation of a new lifestyle created by the young generation in shopping malls.
\end{abstract}

Słowa kluczowe: centra handlowe; czas wolny; model zachowań

Keywords: free time; malls (centres); model of behavior; shopping

Otrzymano: 20 grudnia 2014

Received: 20 December 2014

Zaakceptowano: 11 lipca 2015

Accepted: 11 July 2015

Sugerowana cytacja / Suggested citation:

Wójtowicz, B. (2015). Centa handlowe jako miejsca usług turystycznych w zakresie spędzania wolnego czasu przez mieszkańców Kielc. Prace Komisji Geografii Przemystu Polskiego Towarzystwa Geograficznego, 29(3), 97-110. 


\section{WSTĘP}

Pojawienie się w przestrzeni regionu świętokrzyskiego w XXI wieku centrów handlowych ze zróżnicowaną ofertą usługową, gdzie obok hipermarketu znajdują się galerie z licznymi punktami usługowymi, w znacznym stopniu wpłynęło na kierunki codziennych przemieszczeń ludności, głównie w Kielcach - największym mieście regionu. W stosunkowo krótkim czasie centra te zaczęły przyciągać dużą liczbę mieszkańców miasta i okolicznych miejscowości. Również kreowanie przez media konsumpcyjnego stylu życia wpłynęło na wzrost zainteresowania tymi obiektami, które G. Ritzer (2001) i G. Makowski (2004) nazywają „świątyniami konsumpcji”, a w których oprócz zakupów i korzystania z różnorodnego rodzaju usług można spędzić wolny czas, wykorzystując do tego celu bogatą ofertę rekreacyjno-rozrywkową. Powstały wielofunkcyjne przestrzenie, w których dominuje wzorzec zachowań ludyczno-towarzyski, który zdaniem B. Jałowieckiego (2005) stał się również elementem stylu życia mieszkańców i atrakcją turystyczną osób odwiedzających miasto.

\section{SpęDZANIE WOLNEGO CZASU W CENTRACH HANDLOWYCH}

Wielu ludzi spędza weekendy na zakupach w hipermarketach. Centra handlowe przygotowują swoją ofertę tak, by przyciągnąć całe rodziny. Dla małych dzieci organizuje się miejsca zabaw, pozwalające rodzicom spokojnie zrobić zakupy, aby po nich mogli pójść na obiad lub kawę w pasażu handlowym przyległym do hipermarketu. W okresie świątecznym centra handlowe kuszą mikołajkowymi prezentami dla dzieci, organizują imprezy okolicznościowe, takie jak Dzień Matki, czy Dzień Dziecka (Rochmińska, 2012). Starają się przekonywać, że są nie tylko przestrzenią konsumpcji, ale i bezpiecznym azylem dla całych rodzin. Wiele rodzin nie widzi innej alternatywy na spędzanie wolnego czasu, jak wybranie się na zakupy. Kupują dla czystej przyjemności, nawet rzeczy, które okazują się niepotrzebne, tylko po to, by poprawić sobie humor samym faktem kupowania.

Za prekursora badań geograficznych nad spędzaniem wolnego czasu w centrach handlowych uważa się W. Wilka, który w 2003 roku opublikował artykuł dotyczący zakupów w wielkich centrach handlowych i towarzyszącej im bardzo często rozrywki, która stała się nieodłącznym elementem nowego znaczenia centrum handlowego (Rochmińska, 2012). Podobne badania nad centrami handlowymi jako nowymi produktami i atrakcjami turystycznymi prowadzone były w różnych ośrodkach akademickich w Polsce, m.in. w ośrodku warszawskim przez M. Fuhramann (2008), S. Dudek-Mańkowską i M. Fuhramann (2009), G. Levytską i E. Kwiatkowską (2009). W ośrodku poznańskim badania prowadzone były głównie przez K. Majchrzaka (2007), a w ośrodku katowickim przez A. Górnego (2010). Dużą aktywność badawczą w tym zakresie wykazuje w ostatnich latach ośrodek łódzki, w którym badania są prowadzone przez A. Chrzanowską i A. Rochmińską (2012). Ośrodek krakowski również prowadził badania na ten temat, głównie dotyczące sposobów spędzania wolnego czasu w galeriach handlowych. Badaczami, którzy zajmowali się tym problemem, są S. Bosiacki i P. Rydlewski (2009). W niniejszym artykule przedstawiono wyniki badań dotyczące spędzania wolnego czasu w galerii handlowej Echo, miejsca zakupów kielczan. 


\section{Problematyka BADAWCZA}

Centra handlowe pojawiły się w przestrzeni miejskiej Polaków jako miejsce zakupów. Współczesne społeczeństwo jednak nieco inaczej postrzega rolę zakupów w centrach handlowych. Z czynności obowiązkowych zakupy przemieniły się w przyjemność oraz formę zagospodarowywania i spędzania wolnego czasu. Wizyty w centrach handlowych stały się generatorem zachowań związanych z wolnym czasem wielu mieszkańców.

Celem badań diagnostycznych było przedstawienie roli, jaką we współczesnym świecie ogrywają zakupy dla mieszkańców średnich miast oraz określenie, na ile centra handlowe stanowią dla nich formę usług turystycznych, np. spędzania wolnego czasu. Sformułowano również cele szczegółowe w formie pytań:

- Jakie są główne powody odwiedzania galerii handlowej?

- W jaki sposób mieszkańcy Kielc i okolicy spędzają wolny czas Galerii Echo?

- Jakie są determinanty preferencji respondentów względem centrum handlowego Galeria Echo?

- Jakie są ulubione miejsca i formy spędzania wolnego czasu w Galerii?

Badania zostały przeprowadzone na terenie galerii przez zastosowanie doboru warstwowo-losowego. Podstawowym narzędziem badawczym był kwestionariusz ankiety składający się z pytań otwartych i zamkniętych. Badaniami objęto 408 osób, z czego do analizy uwzględniono 393 ankiety, pozostałe nie były brane pod uwagę ze względu na ich nierzetelne wypełnienie. W badaniach wykorzystano również obserwację terenową i metodę swobodnego wywiadu przeprowadzonego z respondentami, aby dokonać szczegółowego opisu społeczności spędzającej wolny czas w galerii handlowej.

\section{Centrum handlowe a Pojęcie Wolnego czasu}

W Polsce za centrum handlowe uważa się „nieruchomość handlową, która została zaplanowana, zbudowana oraz jest zarządzana jako jeden podmiot handlowy, składający się ze wspólnych części, o minimalnej powierzchni 5 tys. m² (Ledwoń, 2009). Duże obiekty handlowe stały się miejscem spędzania wolnego czasu szczególnie dla mieszkańców dużych miast (Fatyga, 2009).

Czas wolny, wg A. Kamińskiego (1989), to czas nieprzeznaczony na pracę zarobkową, systematyczne kształcenie się, zaspokajanie elementarnych potrzeb fizjologicznych i stałe obowiązki domowe, który można wykorzystać na odpoczynek, życie rodzinne, pracę społeczną. B. Jung (1989) czas wolny rozumie jako czas pozostający do dyspozycji jednostki czy grupy społecznej po wypełnieniu przez nie obowiązków zawodowych (czas pracy i obowiązków).

Przeprowadzone badania pozwoliły autorce na przedstawienie modelu zachowań osób odwiedzających galerię, który stanowi przejaw nowego stylu życia wykreowanego przez młode pokolenie. 


\section{GALERIA ECHO JAKO MIEJSCE ZAKUPÓW I SPĘDZANIA WOLNEGO CZASU}

Galeria Echo w Kielcach to jedno z największych centrów handlowo-rozrywkowych w Polsce. Jest obiektem czteropiętrowym, posiadającym 11 wind, 42 odcinki ruchomych schodów, 300 sklepów, parking na 2,3 tys. miejsc z systemem odszukiwania aut. Znajduje się blisko centrum Kielc, przy ulicy Świętokrzyskiej 20 (ryc. 1).

Ryc. 1. Położenie Galerii Echo w Kielcach

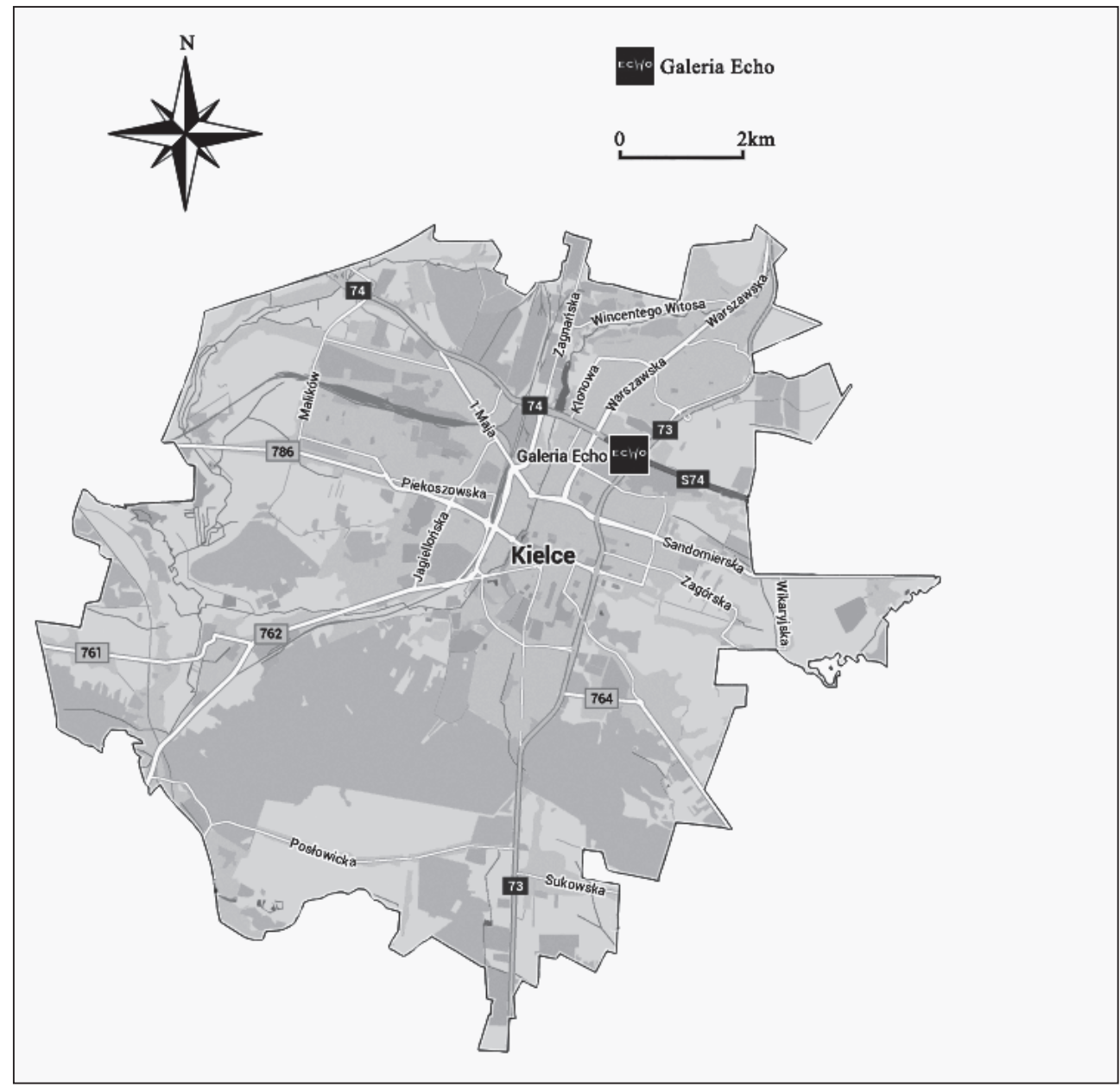

Źródło: opracowanie własne

Galeria Echo przyciąga tych wszystkich, którzy cenią sobie zupełnie nową jakość robienia zakupów i rozrywkę na najwyższym poziomie. Proponuje nie tylko znakomite jedzenie, kino, kręgle czy fitness, ale także spotkania ze sztuką. Jest doskonałym miejscem na artystyczne wystawy, koncerty, imprezy dla dzieci i młodzieży, spotkania twórców 
design - tworzy znakomity klimat dla takich przedsięwzięć. Galeria Echo to nie tylko miejsce na zakupy - to także sposób na spędzanie wolnego czasu dla całej rodziny. Spragnieni aktywnych form wypoczynku mogą poćwiczyć w centrum PURE Fitness. Spotkanie w gronie przyjaciół może uatrakcyjnić urządzenie sobie turnieju w komfortowej, dwunastotorowej kręgielni. Młodsze dzieci mają możliwość spędzenia czasu na ponad $300 \mathrm{~m}^{2}$ nowoczesnego centrum zabaw, mogą też wraz z rodzicami wybrać się do jednej z siedmiu odnowionych, nowoczesnych sal kinowych. Po całym dniu zakupów i rozrywek można skorzystać z posiłku lub deseru w jednej z 21 restauracji i kawiarni. Klienci mogą wybierać z bogatej oferty aż 300 sklepów i punktów handlowych wiodących marek modowych, m.in. H\&M, Zara, Reserved, Kappahl, Cubus, Answear, TKMaxx, Stradivarius, Bershka, Pull\&Bear, C\&A, Guess, Tussardi Jeans, Wittchen, New Look, Peacocks, S.Oliver, Motivi, Strellson, Pierre Cardin, Tally Weijl, Camaieu, Jacqeline Riu, Voëgele, obuwniczych, m.in.: Kazar, Venezia, Prima Moda, Ecco Shoes, Ryłko, sportowych, m.in.: Go Sport, Active Sport, 4F Sport, Wsół Sport, jubilerskich, m.in.: W. Kruk, Apart, Jubitom, dziecięcych, m.in.: Smyk, Wójcik, Beep Young Fashion, Bartek oraz salonów mediów RTV Euro AGD, Sony Cente (http://www. inwestycje.kielce.pl/old/echo_galeria_echo2.htm.).

\section{CHARAKTERYSTYKA BADANYCH}

Osoby objęte badaniami to przede wszystkim ludzie młodzi. Ponad $60 \%$ badanych to osoby poniżej 33. roku życia i tylko $19,8 \%$ powyżej 56. roku życia, pozostali $(20,1 \%)$ to osoby z grupy wiekowej między 34 a 55 rokiem życia (ryc. 2).

Ryc. 2. Struktura respondentów odwiedzających Galerię Echo w Kielcach wg wieku

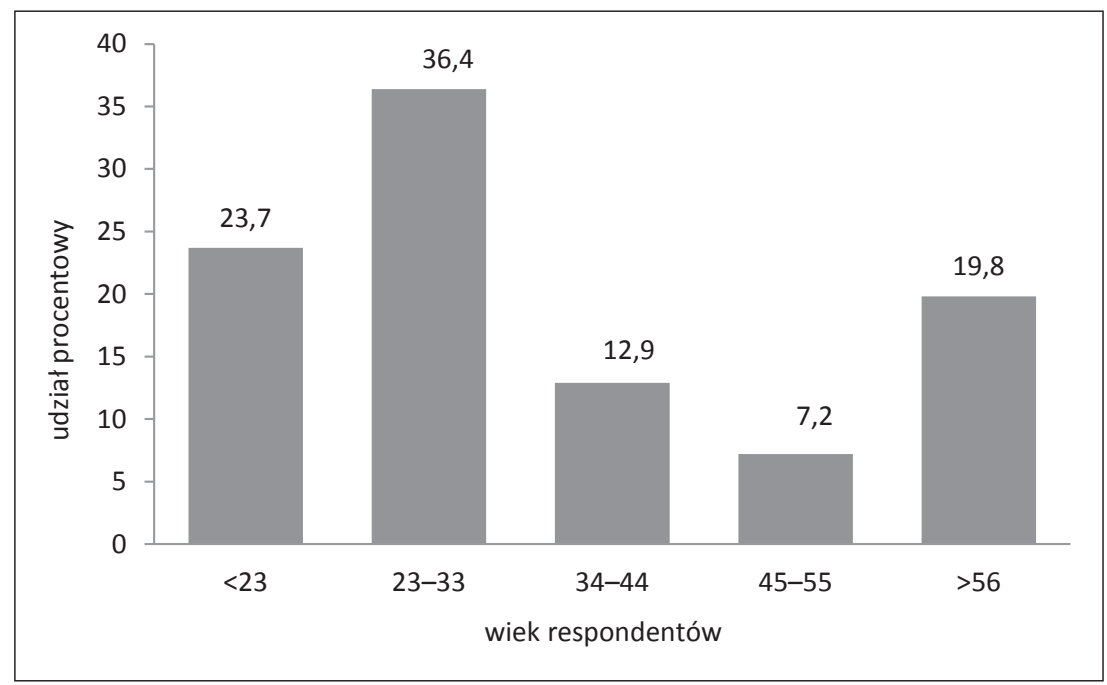

Źródło: opracowanie własne na podstawie przeprowadzonych badań (2014) 
Jeśli chodzi o wykształcenie, to przeszło $70 \%$ badanych miało wykształcenie wyższe $(73,4 \%)$, pozostali legitymowali się wykształceniem średnim/policealnym $(12,9 \%)$ oraz zawodowym $(9,4)$, a tylko 4,3\% podstawowym (uczniowie szkół gimnazjalnych) (ryc. 3).

W badaniach ankietowych autorka starała się uzyskać podstawowe informacje na temat spędzania wolnego czasu przez kielczan w centrum handlowym Galeria Echo. Mieszkańcy Kielc (393 osoby) jako główny powód wizyty w centrum handlowym wymienili zakupy $(89,9 \%)$, przeszło co trzeci respondent wskazał na możliwość spędzenia wolnego czasu (35,6\%), spotkania z przyjaciółmi wskazało $63,7 \%$ badanych, rozrywkę $34,2 \%$, korzystanie z usług gastronomicznych $29,4 \%$, spotkania biznesowe $8,7 \%$, imprezy i pokazy $13,9 \%$, poznanie nowych trendów oraz nowości $23,7 \%$, a korzystanie z innych oferowanych usług $15,2 \%$ (ryc. 4).

Jednym z problemów badawczych w ramach prowadzonych badań empirycznych było ustalenie determinant preferencji respondentów względem centrum handlowego Galeria Echo. Dążono do określenia przyczyn rosnącego zainteresowania mieszkańców centrami handlowymi. Badania potwierdzają, że istotną rolę odgrywa szeroki asortyment towarów i ich cena $(51,3 \%)$, robienie kompleksowych zakupów $(47,9 \%)$, godziny otwarcia $(43,6 \%)$, dostępny parking - miejsca postojowe $(39,6 \%)$, liczne promocje $(33,4)$ i szeroka oferta usług $(33,2 \%)$. Mniejsze znaczenie mają dobre warunki do wypoczynku $(8,6 \%)$, bezpieczeństwo $(9,4 \%)$ oraz moda na przebywanie w galerii $(18,7 \%)$ czy przyjazna atmosfera $(19,6 \%)$. Ta ostania może być związana z tym, iż to klientami galerii są głównie ludzie młodzi, którzy przychodzą jedynie oglądać i przymierzać ubrania, co nie zawsze budzi aprobatę sprzedających (ryc. 5).

Ryc. 3. Struktura respondentów odwiedzających Galerię Echo w Kielcach wg wykształcenia

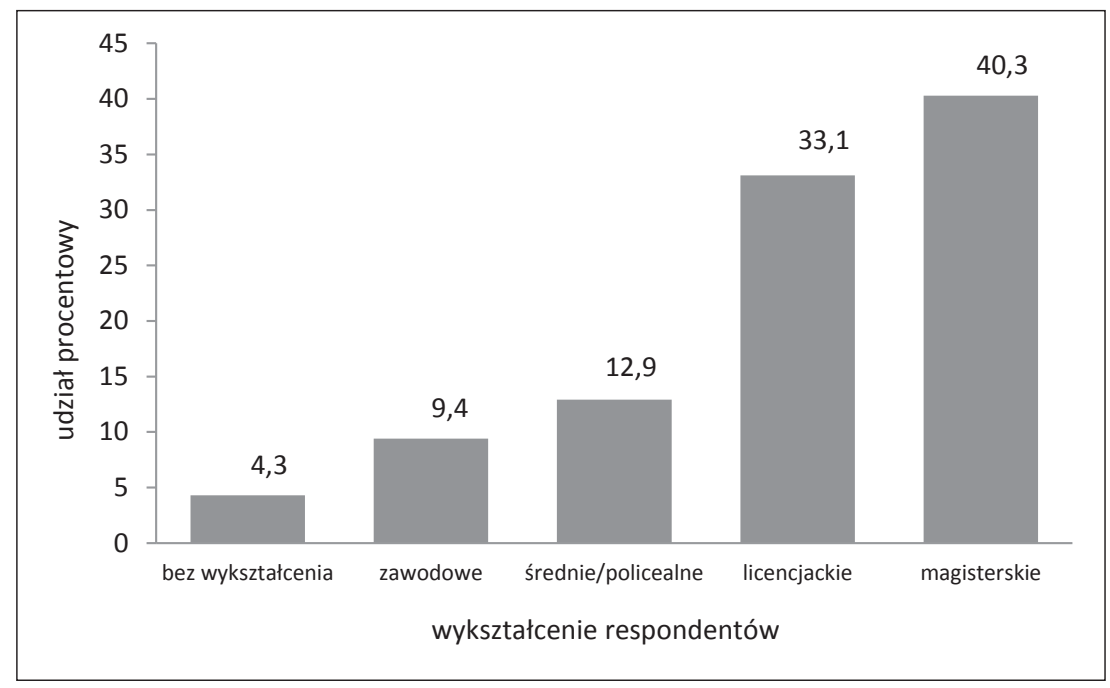

Źródło: opracowanie własne na podstawie przeprowadzonych badań (2014) 
Ryc. 4. Główne cele odwiedzania Galerii Echo w opinii respondentów

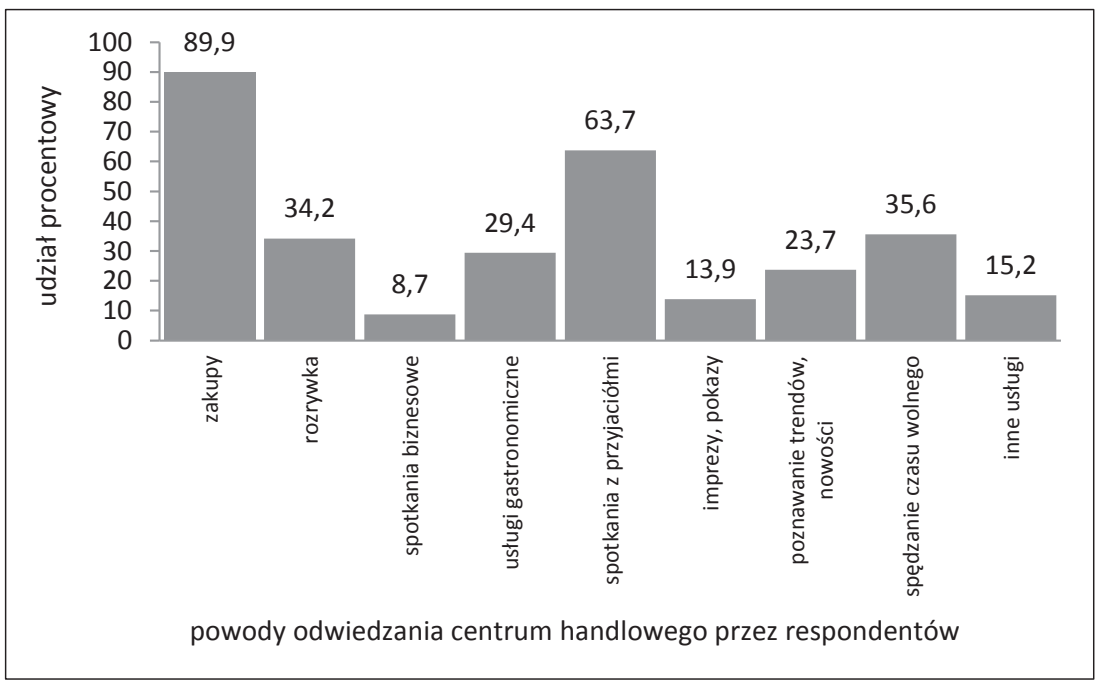

Źródło: opracowanie własne na podstawie przeprowadzonych badań (2014)

Ryc. 5. Determinanty preferencji respondentów względem Galerii Echo

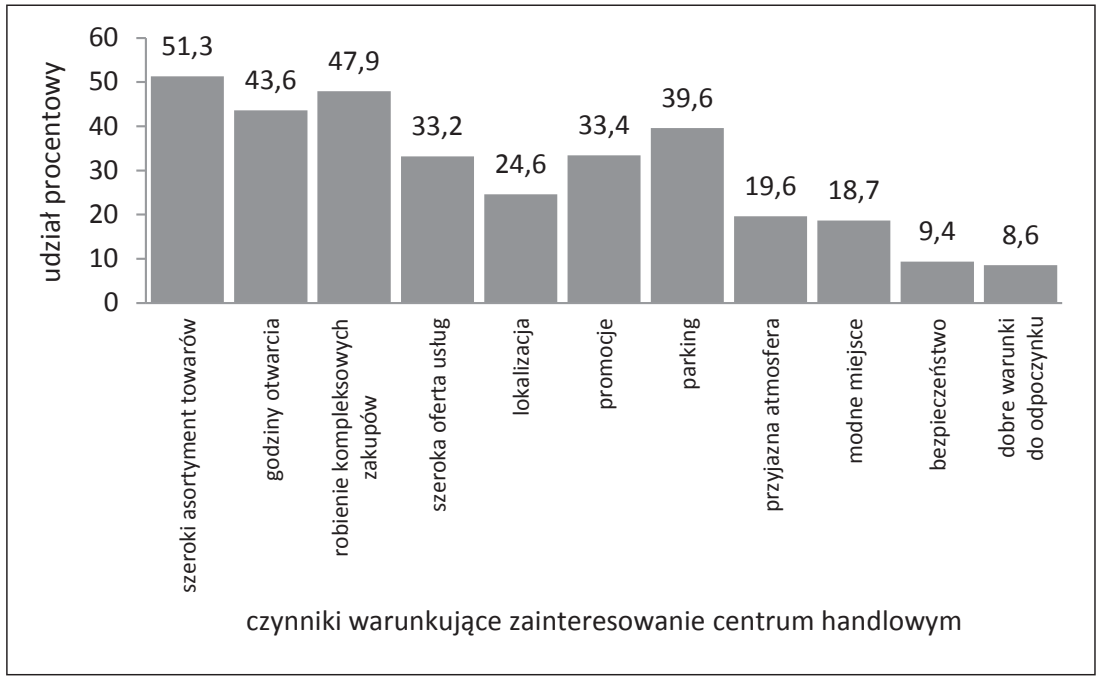

Źródło: opracowanie własne na podstawie przeprowadzonych badań (2014)

Oprócz placówek handlowych nowoczesne centra handlowe oferują szeroki wybór placówek usługowych. Wśród nich czołowe miejsce stanowią punkty usług gastronomicznych, dlatego respondentów zapytano również o korzystanie z nich. 
Respondenci, jak wynika z badań, wybierają placówki gastronomiczne oraz usługi przez nie świadczone ze względu na pewne korzyści. Najważniejszym czynnikiem decydującym o konsumpcji posiłków poza domem - w galerii - jest szeroka oferta lokali, na co wskazało $32,8 \%$ respondentów. Dla blisko co piątej osoby (19,7\%) kryterium wyboru był smak jedzenia (dobre jedzenie), a 15,6\% podkreśliło przyjemną atmosferę panującą w lokalu, zaś ok. $14,3 \%$ respondentów przyciągają przystępne ceny. Były również takie osoby, które wskazały jako powód wyboru lokalu zdrowe jedzenie, co w obecnych czasach nabiera istotnego znaczenia, szczególnie wśród dzieci i młodzieży, którzy przez brak ruchu i niezdrowe odżywianie mają problemy z otyłością i nadwagą (ryc. 6). Wiele osób odwiedzających Galerię Echo wskazało, iż ważnym czynnikiem ich częstego pobytu w galerii, oprócz zakupów i korzystania z szerokiej oferty usługowej, jest możliwość spędzenia wolnego czasu (35,6\%). Wśród tych osób przeszło 76\% robi także zakupy, korzysta z usług gastronomicznych (36,3\%), zapoznaje się z nowymi towarami $(29,9 \%)$, a także bierze udział w organizowanych imprezach i pokazach $(19,7 \%)$ oraz rozrywce $(16,7 \%)$ (ryc. 7$)$.

Ulubionym miejscem spędzania wolnego czasu przez mieszkańców Kielc i okolicy jest kino Helios z siedmioma nowoczesnymi salami kinowymi (1,59 tys. miejsc), w którym swój wolny czas spędza ponad 39,2\% badanych (ryc. 8).

Wśród aktywnych form (sport, fitness) w Galerii Echo ulubionym sposobem spędzania wolnego czasu, a także okazją, by zabrać ze sobą rodzinę i zasmakować sportowych emocji, jest gra w kręgle (bowling) (18,7\%) (ryc. 8). Młodzi ludzie oraz biznesmeni korzystają z klubu fitness Jatomi, w którym mają do dyspozycji w pełni wyposażoną strefę treningu siłowego, saunę, solarium oraz kawiarenkę internetową (13,6\%) (ryc. 9).

Ryc. 6. Determinanty preferencji respondentów w korzystaniu z usług gastronomicznych w Galerii Echo

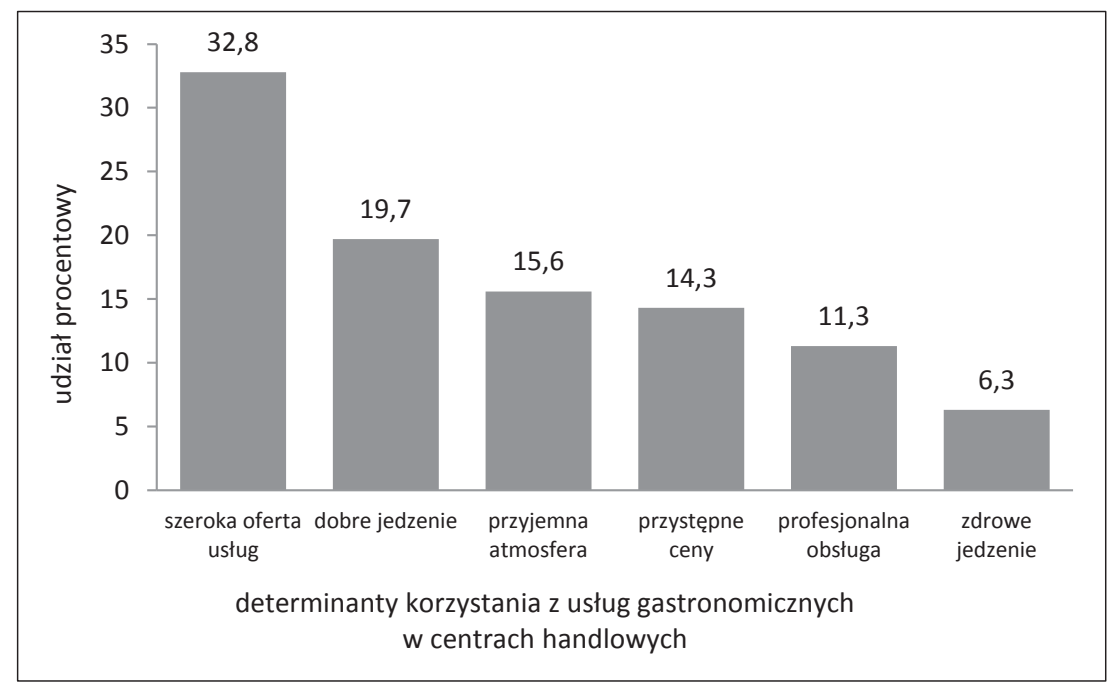

Źródło: opracowanie własne na podstawie przeprowadzonych badań (2014) 
Ryc. 7. Strefy działalności Galerii Echo stanowiące jej atut w opinii respondentów

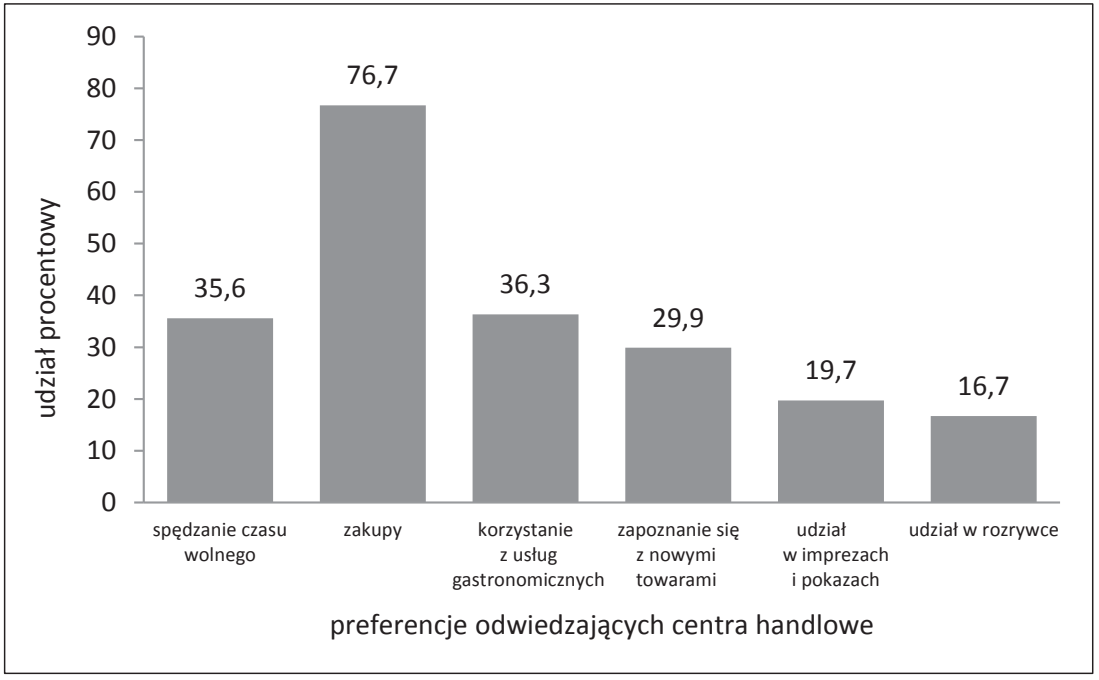

Źródło: opracowanie własne na podstawie przeprowadzonych badań (2014)

Ryc. 8. Najatrakcyjniejsze miejsca spędzania wolnego czasu w Galerii Echo przez respondentów

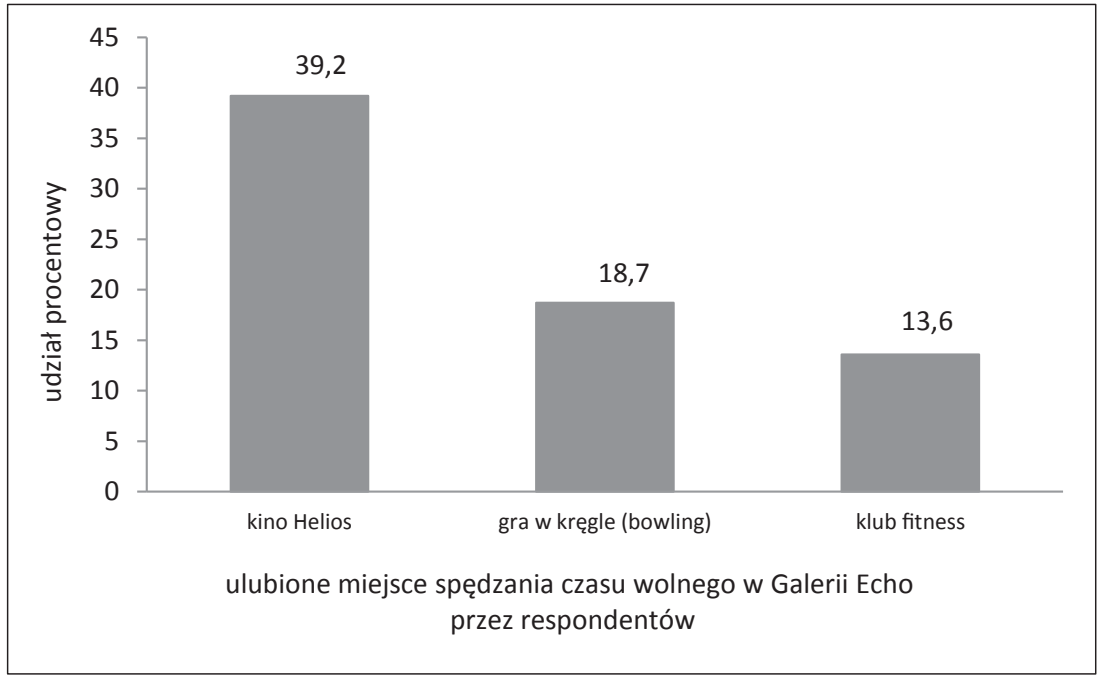

Źródło: opracowanie własne na podstawie przeprowadzonych badań (2014) 
Ryc. 9. Sfery działalności Galerii Echo jako centrum handlowego stanowiące atut w opinii respondentów

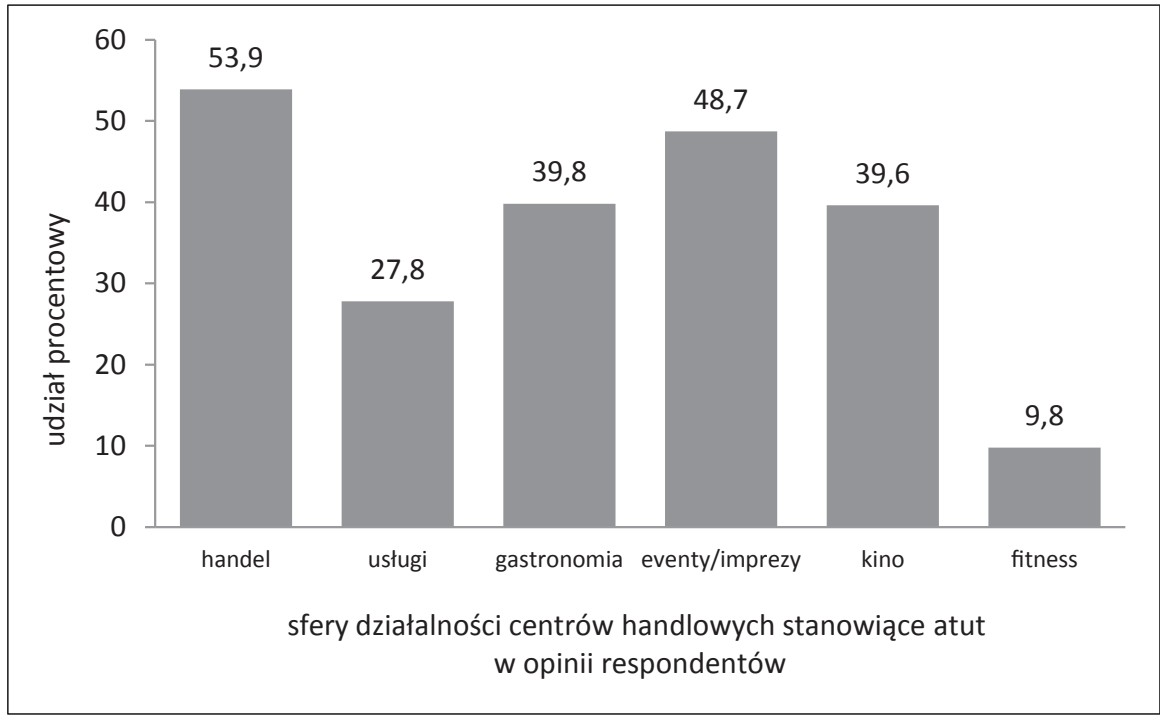

Źródło: opracowanie własne na podstawie przeprowadzonych badań (2014)

Istotną rolę w spędzaniu wolnego czasu w galerii odgrywają także dzień tygodnia i częstotliwość pobytu przebywania w galerii. Osoby spędzające wolny czas w galerii handlowej $\mathrm{z}$ reguły bywają $\mathrm{w}$ niej podczas dni weekendowych. Sobota jest najczęściej wskazywanym dniem wizyt - w ten dzień co drugi respondent $(54,3 \%)$ przyznaje się do pobytu w takim miejscu. Również w piątki $(29,8 \%)$ i niedziele $(37,4 \%)$ przebywa w centrum handlowym duża część ankietowanych.

Dla porównywalnej grupy osób (39,3\%) nie ma reguły, trudno jest im jednoznacznie wskazać konkretne dni tygodnia wizyt w tym miejscu (ryc. 10). Należy przy tym podkreślić, że tego typu osoby bywają w centrum handlowym raz w tygodniu $(57,6 \%)$, a do 2-3 razy w miesiącu prawie $90 \%$ respondentów.

Analizując dane przedstawione na ryc. 11, można dostrzec zależność, wg której młodsi respondenci częściej deklarowali wizyty w galerii codziennie, kilka razy w tygodniu lub raz w tygodniu niż respondenci starsi. Osoby z grupy wiekowej powyżej 56 lat deklarowały najrzadsze korzystanie z oferty Galerii Echo, kilka razy w miesiącu $(7,3 \%)$ i rzadziej (5\%). Dynamizm zmian strukturalnych zachodzących nieustannie na rynku w sposób istotny wpływa na zmiany postaw i zachowań osób zarówno na rynku, jak i w innych sferach życia społecznego. Jak wykazały badania, respondenci odwiedzający galerię handlową podejmują działania powodowane różnorodnymi czynnikami. Niektórzy przywiązują się do marki, inni mniej lub bardziej świadomie wybierają produkty odwołujące się do ich przekonania, inni poszukują rozrywki, a jeszcze inni przychodzą spędzić wolny czas w gronie przyjaciół czy z rodziną. Nie do końca jasne są przesłanki skłaniające ludzi do podejmowania określonych zachowań, począwszy od procesu decyzyjnego, poprzez ich odczucia czy też wpływ różnych czynników na dokonywanie zakupów po wybór i reakcje na różne formy spędzania wolnego czasu w galeriach handlowych. Przeprowadzone badania pozwoliły na przedstawienie modelu zachowań 
(ryc. 12) tych czynników, które wpływają na postawy osób odwiedzających galerie handlowe i stanowią przejaw nowego stylu życia wykreowanego przez młode pokolenie.

Ryc. 10. Dni tygodnia, w których respondenci najczęściej spędzają wolny czas w galerii

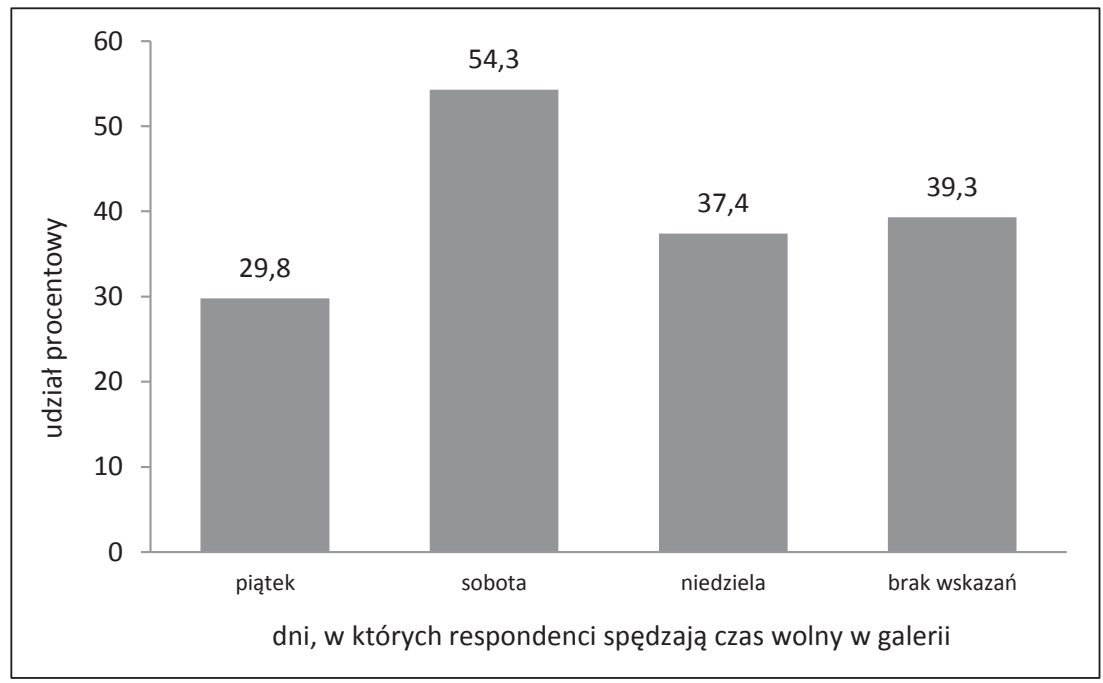

Źródło: opracowanie własne na podstawie przeprowadzonych badań (2014)

Ryc. 11. Częstotliwość wizyt respondentów w Galerii Echo

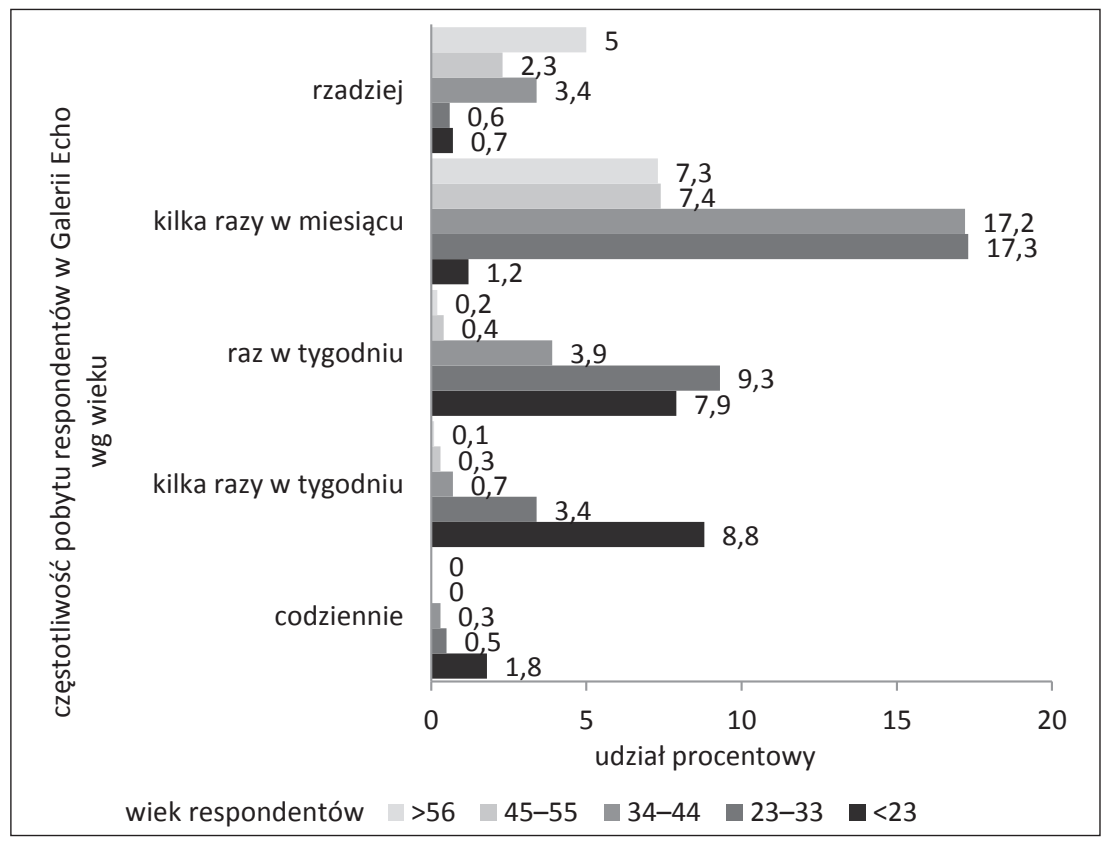

Źródło: opracowanie własne na podstawie przeprowadzonych badań (2014) 
Ryc. 12. Model zachowań osób odwiedzających galerie handlowe
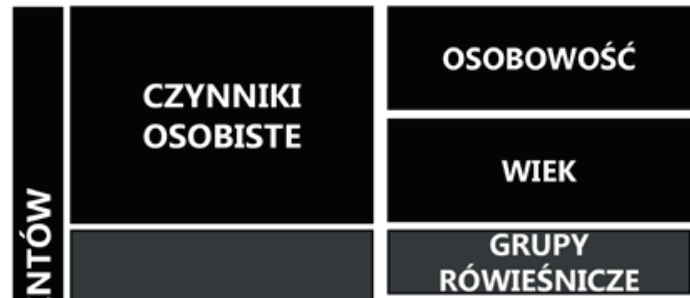

CZYNNIKI

SPOŁECZNE

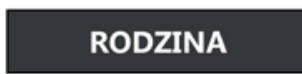

WYCHOWANIE

WZORCE ZACHOWAŃ

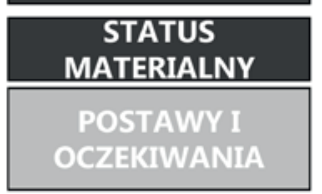

ROLA

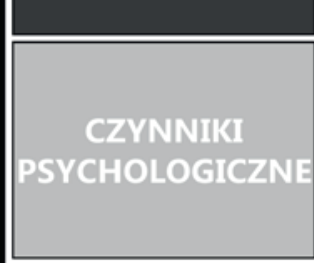

MATERIALNY

SPOKECZNA

OCZEKIWANTA

WIEDZA I

UMIEJĘTNOŚCI

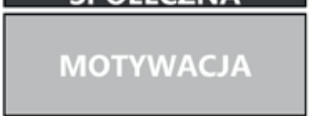

POSTRZEGANIE

KULTURA

CZYNNIKI KULTUROWE

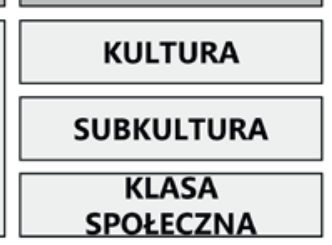

Źródło: opracowanie własne

Podsumowanie

Na podstawie przeprowadzonych badań można stwierdzić, że pod wpływem zachodzących przemian społeczno-gospodarczych zmianie uległy potrzeby, wymagania oraz zachowania osób odwiedzających galerie handlowe. Badane osoby odwiedzają centra handlowe nie tyko w celach zakupowych, ale także w towarzyskich oraz rozrywkowych. Nowoczesne galerie handlowe są coraz częściej również miejscem spędzania wolnego czasu. Cele odwiedzin Galerii Echo różnicują socjodemograficzne cechy badanych osób, jednak nie są to jedyne determinanty powodujące zainteresowanie nowoczesnymi centrami handlowymi. Ważną rolę odgrywają czynniki dotyczące samego centrum i tego, co ma ono do zaoferowania. Szeroki asortyment towarów, kompleksowość zakupów, dogodne położenie i dojazd oraz duży wybór różnego rodzaju usług, głównie gastronomicznych, wypoczynkowych i rozrywkowych, stanowią magnes przyciągający do jego odwiedzin. Wizyty w galerii handlowej stały się generatorem zachowań pozazakupowych i mają istotne znaczenie w budżecie spędzania wolnego czasu wielu osób. Stały się one przyjemnością i formą zagospodarowania oraz spędzania wolnego czasu szczególnie wśród ludzi młodych i wykształconych, o dobrym statusie materialnym. Model czynników wpływających na zachowania tych osób zapewne 
będzie się coraz dalej rozwijał, dlatego trzeba mieć na uwadze te nowe zachowania, które stanowią przejaw nowego stylu życia młodego pokolenia.

\section{Literatura \\ References}

Bosiacki, S., Rydlewski, P. (2009). Wielkomiejskie centra i galerie handlowe jako miejsca rekreacji i atrakcje turystyczne. Zeszyty Naukowe, 16.

Chrzanowska, A., Rochmińska, A. (2012). Zachowania nabywcze i przestrzenne klientów Galerii Łódzkiej w Łodzi. Acta Universitatis Lodziensis. Folia Geographica Socio-Oeconomica, 12.

Dudek-Mańkowska, S., Fuhramann, M. (2009). Centra handlowe trzeciej generacji w Warszawie jako nowe produkty turystyczne. W: A. Stasiak (red.). Kultura i turystyka - wspólnie zyskać. Łódź: Wydawnictwo Wyższej Szkoły Turystyki i Hotelarstwa.

Fatyga, B. (2009). Czas wolny. W: Raport o stanie i zróżnicowaniach kultury miejskiej w Polsce. Warszawa: Ministerstwo Kultury i Dziedzictwa Narodowego.

Fuhramann, M. (2008). Znaczenie turystyczne centrów handlowych nowej generacji w Warszawie. Turystyka i Hotelarstwo, 14.

Górny, A. (2010). Trzymając telewizyjnego pilota czy ściskając kierownicę roweru? Sposoby spędzania czasu wolnego w przestrzeni miasta późnonowoczesnego na przykładzie Katowic. W: I. Bukowska-Floreńska (red.). Studia Etnologiczne i Antropologiczne, 10.

Jałowiecki, B. (2005). Przestrzeń ludyczna - nowe obszary metropolii. Studia Regionalne i Lokalne, 3. Jung, B. (1989). Ekonomia czasu wolnego. Zarys problematyki. Warszawa: Wydawnictwo Naukowe PWN.

Kamiński, A. (1989). Czas wolny i jego problematyka społeczno-wychowawcza. Wrocław: Zakład Narodowy im. Ossolińskich.

Ledwoń, S. (2009). Przekształcenia obszarów śródmiejskich z udziałem funkcji handlowej. W: P. Lorens, J. Martyniuk-Pęczek (red.). Wybrane zagadnienia z rewitalizacji miast. Gdańsk: Wydawnictwo Urbanista.

Levytska, G., Kwiatkowska, E. (2009). Nowe tendencje w zachowaniach polskich konsumentów na rynku usług gastronomicznych. Marketing i Rynek, 16(8), 23-26.

Majchrzak, K. (2007). Centrum handlowe jako atrakcja turystyczna ery postturystyki na przykładzie Starego Browaru w Poznaniu. Ekonomiczne Problemy Turystyki, 466(9).

Makowski, G. (2004). Światynia konsumpcji: geneza i spoleczne znaczenie centrum handlowego. Warszawa: Wydawnictwo Trio.

Ritzer, G. (2001). Magiczny świat konsumpcji. Warszawa: MUZA.

Rochmińska, A. (2012). Centra handlowe - miejsca spędzania czasu wolnego przez Łodzian Acta Universitatis Lodziensis. Folia Geographica Socio-Oeconomica, 11.

Bożena Elżbieta Wójtowicz, dr hab., prof. nadzwyczajny, Uniwersytet Pedagogiczny, Wydział Geograficzno-Biologiczny, Instytut Geografii, Zakład Dydaktyki Geografii. Kierownik Zakładu Dydaktyki Geografii Instytutu Geografii Uniwersytetu Pedagogicznego w Krakowie. Geograf, dydaktyk geografii, podróżnik, zwiedziła większość krajów europejskich oraz Kubę, Dominikanę, Meksyk, Indie, Nepal, Egipt, Maroko, Jordanię, Turcję. Opublikowała ponad 190 prac naukowych w kraju i za granica. Autorka monografii naukowej Geografia, rozwój zrównoważony, edukacja ekologiczna oraz współautorka i redaktorka prac o charakterze monograficznym, m.in. Przyroda województwa świętokrzyskiego, Funkcje turystyki i krajoznawstwa w strategii rozwojów regionów w Polsce, Turystyka i ekologia rozbudzanie potrzeb poznawczych i świadomości społeczeństwa, Ksztatcenie i dokształcanie nauczycieli geografii w Polsce i w krajach Unii Europejskiej, Edukacyjne zajęcia terenowe w Świętokrzyskim Parku Narodowym. Współautorka podręczników szkolnych: Geografia. Krajobrazy Polski do klasy 4, 
Geografia. Ziemia - nasza planeta do klasy 6, Przyroda do klasy 4 i 5. Specjalistka z zakresu geografii, turystyki i rekreacji, dydaktyki geografii oraz ochrony środowiska.

Bożena Elżbieta Wójtowicz, Ph.D., prof. Pedagogical University of Cracow, Faculty of Geographical and Biological, Institute of Geography, Department of Geography Teaching. Head of the Department of Geography, Institute of Geography Teaching of the Pedagogical University of Cracow. Geographer, geography teacher, traveller, visited most of the European countries, Cuba, Mexico, Dominican Republic, India, Nepal, Egypt, Morocco, Jordan, Turkey. She has published over 190 scientific papers in the country and abroad. The author of the monograph Geography Sustainable Development Environmental Education and co-author and editor of a monographic work, including Świętokrzyskie Voivodeship, Tourism and ecology - to foster the cognitive needs and public awareness, Education and training of teachers of geography in Poland and in the European Union, Educational fieldwork in Świętokrzyski National Park. Co-author of textbooks: Geography. Polish Landscapes Class 4, Geography. Earthour planet to Grade 6, Nature Class 4 and 5. Specialist in the field of geography, tourism and recreation, teaching geography and the environment.

\section{Adres/address:}

Uniwersytet Pedagogiczny

Wydział Geograficzno-Biologiczny

Instytut Geografii

Zakład Dydaktyki Geografii

ul Podchorążych 2, 30-084 Kraków, Polska

e-mail: boz.wojt@gmil.com 